\title{
Multiple genetic stocks of longfin squid Loligo pealeii in the NW Atlantic: stocks segregate inshore in summer, but aggregate offshore in winter
}

\author{
K. C. Buresch, G. Gerlach, R. T. Hanlon* \\ Marine Resources Center, Marine Biological Laboratory, Woods Hole, Massachusetts 02543, USA
}

\begin{abstract}
The longfin squid Loligo pealeii is distributed widely in the NW Atlantic and is the target of a major fishery. A previous electrophoretic study of $L$. pealeii was unable to prove genetic differentiation, and the fishery has been managed as a single unit stock. We tested for population structure using 5 microsatellite loci. In early summer (June), when the squids had migrated inshore to spawn, we distinguished 4 genetically distinct stocks between Delaware and Cape Cod (ca. $490 \mathrm{~km}$ ); a 5th genetic stock occurred in Nova Scotia and a 6th in the northern Gulf of Mexico. One of the summer inshore stocks did not show genetic differentiation from 2 of the winter offshore populations. We suggest that squids from summer locations overwinter in offshore canyons and that winter offshore fishing may affect multiple stocks of the inshore fishery. In spring, squids may segregate by genetic stock as they undertake their inshore migration, indicating an underlying mechanism of subpopulation recognition.
\end{abstract}

KEY WORDS: Fisheries • Spawning migration - Microsatellites · Population structure . Population recognition $\cdot$ Null alleles

Resale or republication not permitted without written consent of the publisher

\section{INTRODUCTION}

The high dispersal capability of many marine organisms has typically been associated with low levels of genetic differentiation, especially when compared to terrestrial and freshwater species (Ward et al. 1994, Graves 1998, Waples 1998). Several recent studies using highly variable genetic markers have shown examples of marine organisms that do exhibit population substructure (for reviews see Bohonak 1999, Hellberg et al. 2002). The presence of distinct genetic units within commercially important species bears direct relevance to the management of fisheries.

Population genetic structure of cephalopods is scarcely known. Within the Class Cephalopoda (Phylum Mollusca), the squids (Order Teuthoidea) are one of the most speciose and numerically abundant groups, and play a central role in marine ecosystems (cf. Boyle \& Boletzky 1996). Among the world's inshore fisheries, the loliginid squids (Family Loliginidae) are now one of the most commercially valuable species. These stocks must be managed judiciously due to recent high levels of exploitation.
Most loliginid fisheries, including that for the longfin squid Loligo pealeii (Lesueur 1821), are managed as a single unit stock (NEFSC 1996). The reason for this is that most studies of genetic structuring in squid populations have suggested widespread genetic uniformity (e.g. Garthwaite et al. 1989, Reichow \& Smith 2001, Shaw et al. 1999, 2004). In addition, offshore of the Atlantic coast of the USA, the lack of conspicuous physical oceanographic barriers to gene flow would suggest that separate genetic stocks are unlikely to exist.

Loligo pealeii has a life span $<1 \mathrm{yr}$, due in large part to the very high growth rates that squids achieve (Hatfield et al. 2001), and to the relatively small sizes at which the species is capable of maturing under certain (yet unknown) conditions. Off southern New England (the main fishery), squids are found inshore in summer as they spawn, and offshore during winter in submarine canyons with stable temperatures (Summers 1983). There is evidence that they also undergo substantial north-south migrations on the order of $500 \mathrm{~km}$ or more (Macy \& Brodziak 2001). Recent morphometric studies of size and age at maturity provide evidence 
that the link between inshore and offshore components of the stock may be more complicated than formerly believed: age structure remains nearly constant through winter and spring, and statolith back-aging suggests that spawning recruitment may occur yearround (Macy \& Brodziak 2001).

An allozyme study of Loligo pealeii showed that only 1 locus was polymorphic enough to detect differentiation (Garthwaite et al. 1989). Based upon that single locus, those authors suggested that 3 separate populations of L. pealeii existed along the Atlantic coast of the USA at Virginia, Cape Cod, and Georges Bank. However, the L. pealeii fishery has continued to be managed as a single genetic stock, given the lack of convincing genetic data to the contrary. Because recent increases in value have attracted attention to the $L$. pealeii fishery, and due to refinement of molecular genetic techniques, we decided to use microsatellites (Buresch et al. 2001, Maxwell et al. 2000) to test for population substructure.

\section{MATERIALS AND METHODS}

Sample collection. Squid samples were collected by trawl from 6 inshore areas: Nova Scotia (Stn 1), Cape Cod (Stn 2), Long Island Sound (Stn 3), New Jersey (Stn 4), Delaware (Stn 5), and northern Gulf of Mexico (Stn 6); 1 mid-shelf area: Georges Bank (Stn 7); and 3 offshore areas: Veatch Canyon (Stn 8), Hudson Canyon (Stn 9), and Washington Canyon (Stn 10) (Fig. 1). Inshore summer samples and the mid-shelf sample were collected during the 2001 spawning season from May to June. Winter offshore samples were collected from different years (Table 1). The northern Gulf of Mexico (Stn 6), Hudson Canyon (Stn 9), and Nova Scotia (Stn 1) samples were collected during winter 2000, prior to the inshore summer sampling. Washington (Stn 10) and Veatch (Stn 8) canyons were sampled in winter 2002, after the inshore summer samples.

DNA extraction, amplification and genotyping. Squids were frozen until DNA extraction. Genomic DNA was extracted from 20 to $40 \mathrm{mg}$ of adult arm tip tissue by a variation of the phenol/SDS procedure (Sambrook et al. 1989). Five microsatellite primers (Lfor3, Lp2, Lp4, Lp5 and Lp12) (Maxwell et al. 2000) were applied to each sample. Microsatellites were amplified using the polymerase chain reaction (PCR) in a Perkin Elmer 3700 thermocycler under the following conditions: $300 \mathrm{~s}$ at $95^{\circ} \mathrm{C}$, then 25 to 35 cycles of $30 \mathrm{~s}$ at $95^{\circ} \mathrm{C}, 30 \mathrm{~s}$ at $55^{\circ} \mathrm{C}$, $30 \mathrm{~s}$ at $72^{\circ} \mathrm{C}$, and a final elongation time of $120 \mathrm{~s}$. Reaction mixes contained $1 \mu \mathrm{l}$ of template DNA, $1.5 \mathrm{mM}$ $\mathrm{MgCl}_{2}, 0.2 \mathrm{mM}$ of each nucleotide, $0.1 \mathrm{mM}$ of each primer (1 primer infrared labeled), 0.08 units of Taq polymerase (Promega) with the manufacturer's supplied Buffer B, and deionized water to a final volume of $10 \mu \mathrm{l}$.
PCR products were separated on a $6 \%$ denaturing polyacrylamide gel, and analyzed on a LI-COR 4000 model sequencer. Fragment sizes were determined by comparison to commercial size standards (LI-COR) using GelPro Analyzer software (Media Cybernetics). Samples of alleles of known size were run on each gel as standards to assure correct allele assignment. Allele lengths that could not be determined the first time were repeatedly run until unequivocal assignment.
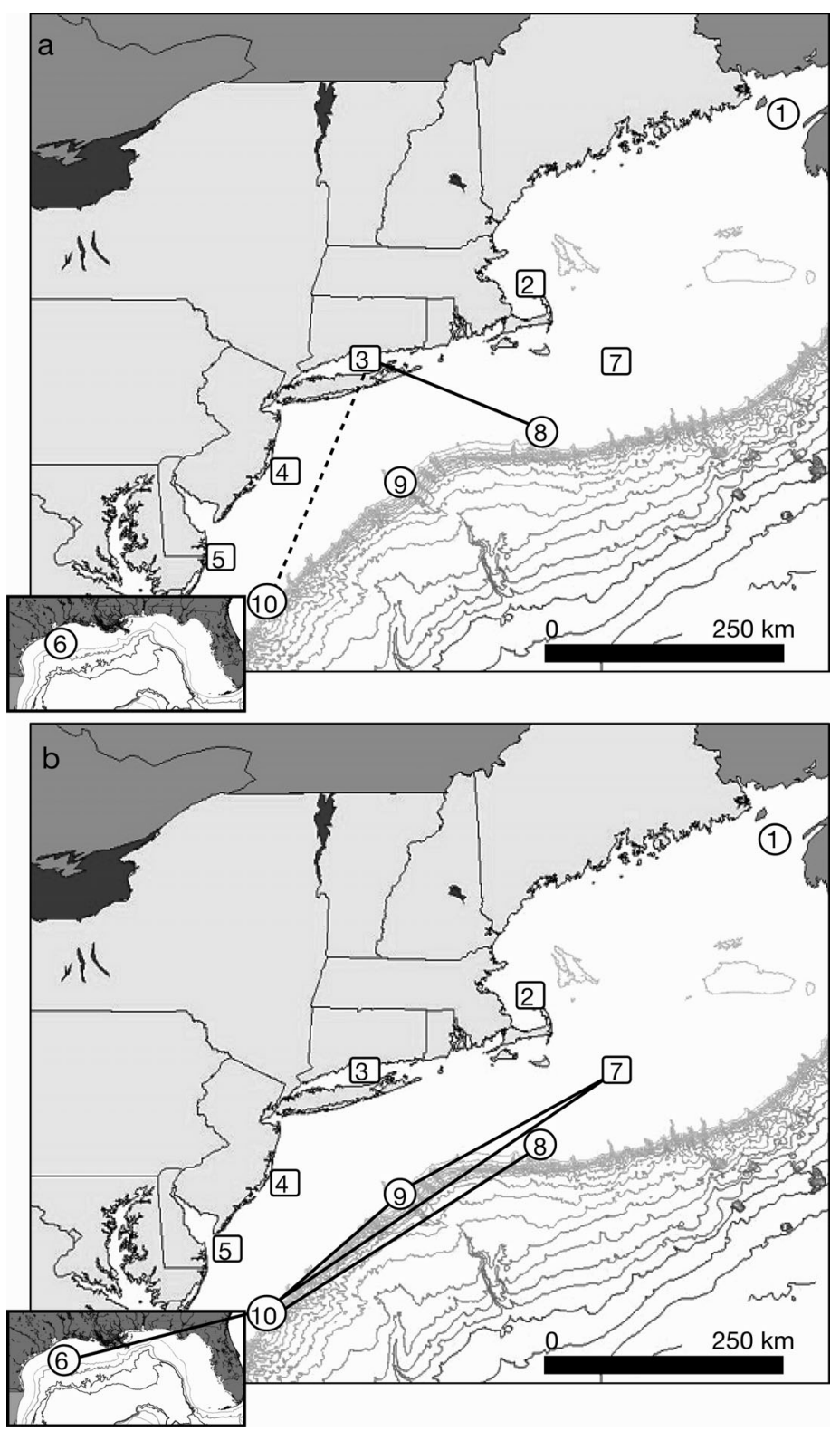

Fig. 1. Loligo pealeii. Sampling stations in the NW Atlantic. (a) Inshore-offshore connections; (b) offshore connections only. Rectangles: summer samples; circles: winter samples. Connecting lines: non-significant differences in allele frequencies (i.e. gene flow) between stocks; dotted line: non-significant $F_{\mathrm{ST}}$ value; inset: Gulf of Mexico sampling station 
Table 1. Loligo pealeii. Sampling stations and collection details (compare with Fig. 1). In: inshore; Mid: mid-shelf; Off: offshore. W: winter; S: summer

\begin{tabular}{|c|c|c|c|c|c|c|}
\hline \multirow[b]{2}{*}{ Stn } & \multirow[b]{2}{*}{ Name } & \multirow[b]{2}{*}{ Latitude } & \multirow[b]{2}{*}{ Longitude } & \multicolumn{3}{|c|}{$\longrightarrow$ Sampling } \\
\hline & & & & Size & Location & Period \\
\hline 1 & Nova Scotia & $44.0^{\circ} \mathrm{N}$ & $66.8^{\circ} \mathrm{W}$ & 45 & In & W 2001-2002 \\
\hline 2 & Cape Cod & $42.0^{\circ} \mathrm{N}$ & $70.2^{\circ} \mathrm{W}$ & 38 & In & S 2001 \\
\hline 3 & Long Island & $41.2^{\circ} \mathrm{N}$ & $72.5^{\circ} \mathrm{W}$ & 93 & In & S 2001 \\
\hline 4 & New Jersey & $39.4^{\circ} \mathrm{N}$ & $74.3^{\circ} \mathrm{W}$ & 76 & In & S 2001 \\
\hline 5 & Delaware & $38.6^{\circ} \mathrm{N}$ & $75.0^{\circ} \mathrm{W}$ & 61 & In & S 2001 \\
\hline 6 & Gulf of Mexico & $29.3^{\circ} \mathrm{N}$ & $94.8^{\circ} \mathrm{W}$ & 45 & In & W 2000-2001 \\
\hline 7 & Georges Bank & $41.5^{\circ} \mathrm{N}$ & $68.5^{\circ} \mathrm{W}$ & 42 & Mid & S 2001 \\
\hline 8 & Veatch Canyon & $40.2^{\circ} \mathrm{N}$ & $69.6^{\circ} \mathrm{W}$ & 34 & Off & W 2001-2002 \\
\hline 9 & Hudson Canyon & $39.5^{\circ} \mathrm{N}$ & $72.0^{\circ} \mathrm{W}$ & 30 & Off & W 2000-2001 \\
\hline 10 & Washington Canyon & $37.4^{\circ} \mathrm{N}$ & $74.5^{\circ} \mathrm{W}$ & 20 & Off & W 2001-2002 \\
\hline
\end{tabular}

is, if the smallest allele was 103, we named the (probably) falsely assigned second allele '100' because we used trinucleotide repeat loci. This introduced a conservative bias because null alleles may consist of several size classes themselves, in which size-homoplasy tends to reduce the 'true' population divergence. We used these corrected alleles for calculating genetic divergence among populations ( $F_{\mathrm{ST}}$ values) and for the Mantel test. Since $R_{\mathrm{ST}}$ values are calculated using similar alleles, they cannot be calculated after correcting for null alleles.
Data analysis. Observed and expected heterozygosities were calculated for each locus, and genotypes were tested for linkage disequilibrium to determine independence of loci using FSTAT version 2.93 updated from Goudet (1995). Genotype and allele frequencies of the microsatellite loci were used to estimate variances in gene frequencies within and among sampling stations. Within subpopulations, deviations from Hardy-Weinberg equilibrium were estimated by $F_{\mathrm{IS}}$ values calculated with FSTAT version 2.93 (Goudet 1995). To determine the degree of genetic divergence among squids from different sampling stations, pairwise $F_{\mathrm{ST}}$ values were calculated (Goudet 1995). When $F_{\mathrm{IS}}$ values indicated that random mating could not be assumed within populations, statistical significance for $F_{\mathrm{ST}}$ values was estimated using an exact $G$-test by randomising genotypes among samples (for details see Goudet 1995).

Mantel matrix correlations (Mantel 1967) were used to compare geographic and genetic distance. We calculated Cavalli-Sforza \& Edwards chord distances (Cavalli-Sforza \& Edwards 1967) to reconstruct evolutionary relationships among our samples. This Euclidean distance was the most efficient measure out of 7 distances compared in reconstructing trees when heterozygosities were high (Takezaki \& Nei 1996). Calculations of these genetic distances were performed by GENETIX (Belkhir et al. 1997). Geographic distance was defined as the straight-line distance between the centres of different collection areas.

Due to high $F_{\mathrm{IS}}$ values observed for most populations, we tested all loci for the probability of containing null alleles using the program MICRO-CHECKER (van Oosterhout et al. 2004). Four loci (Lfor3, Lp 2, Lp 5 and Lp 12) showed null alleles in 1 to several populations. To balance for false assignment of homozygotes, we set the second allele of such individuals to an arbitrary number (smallest allele size minus 1 repeat). That

\section{RESULTS}

All 5 microsatellite loci were highly polymorphic, ranging from 15 to 37 different alleles per locus; loci Lp2 and Lp4 exhibited the greatest number of alleles (Table 2). No significant linkage disequilibrium was found among loci. Observed levels of heterozygosity ranged from 66 to $88 \%$. After correction for null alleles, all populations were in Hardy-Weinberg equilibrium; $F_{\text {IS }}$ values corrected and not corrected for null alleles are shown in Table 3 . The mean $F_{\text {STcorr }}$ value of 0.036 (uncorrected $F_{\mathrm{ST}}$ value $=0.039$ ) for all loci and all 10 samples revealed significant genetic substructuring among all populations of squids (Table 4).

Each of the 4 inshore (Stns 2 to 5) and the mid-shelf (Stn 7) summer samples along the Atlantic coast of the USA (Fig. 1) were genetically distinct from one another; pairwise $F_{\text {STcorr }}$ values ranged from 0.0115 between Georges Bank (Stn 7) and Long Island (Stn 5) to 0.052 between New Jersey (Stn 4) and Cape Cod (Stn 2) (Table 4 ). The overall $F_{\text {STcorr }}$ value among all these inshore samples was 0.033. One of the summer inshore genetic stocks (Long Island, Stn 3) did not show significant differentiation from the winter offshore populations in Veatch (Stn 8) and Washington (Stn 10) canyons, as indicated by statistically non-significant $F_{\text {ST- }}$ corr values in Table 4 and by connecting lines in Fig. 1.

Table 2. Loligo pealeii. Number of alleles per locus and sample station; (additional MICRO-CHECKER corrected alleles (van Oosterhout et al. 2004) not included

\begin{tabular}{|lccccccccccc|}
\hline Locus & Stn 1 & Stn 2 & Stn 3 & Stn 4 & Stn 5 & Stn 6 & Stn 7 & Stn 8 & Stn 9 & Stn 10 & ALL \\
\hline Lfor3 & 12 & 10 & 14 & 13 & 11 & 13 & 14 & 11 & 11 & 10 & 18 \\
Lp2 & 10 & 19 & 14 & 17 & 10 & 10 & 12 & 10 & 9 & 8 & 31 \\
Lp4 & 20 & 14 & 23 & 24 & 23 & 20 & 22 & 20 & 20 & 15 & 37 \\
Lp5 & 8 & 5 & 9 & 6 & 5 & 6 & 7 & 4 & 7 & 5 & 16 \\
Lp12 & 7 & 6 & 5 & 6 & 7 & 5 & 6 & 6 & 5 & 7 & 15 \\
\hline
\end{tabular}


Table 3. Loligo pealeii. $F_{\mathrm{IS}}$ values per locus and sample station before (number above) and after (number below) correction for null alleles using MICRO-CHECKER (van Oosterhout et al. 2004). Superscripted numbers next to corrected $F_{\text {IS }}$ values indicate how many falsely assigned homozygous alleles were corrected. * : indicative adjusted nominal level (5\%) was 0.001 ; ns: nonsignificant; overall corrected $F_{\mathrm{IS}}$ : significance of all corrected $\mathrm{F}_{\mathrm{IS}}$ values

\begin{tabular}{|c|c|c|c|c|c|c|c|c|c|c|}
\hline Locus & Stn 1 & Stn 2 & Stn 3 & Stn 4 & Stn 5 & Stn 6 & Stn 7 & Stn 8 & Stn 9 & Stn 10 \\
\hline Lfor3 & $\begin{array}{l}0.216^{*} \\
0.081^{6}\end{array}$ & $\begin{array}{l}0.063 \\
0.063\end{array}$ & $\begin{array}{l}0.221^{*} \\
0.073^{14}\end{array}$ & $\begin{array}{l}0.018 \\
0.018\end{array}$ & $\begin{array}{l}0.105 \\
0.105\end{array}$ & $\begin{array}{l}0.297^{*} \\
0.125^{7}\end{array}$ & $\begin{array}{l}0.196^{*} \\
0.099^{3}\end{array}$ & $\begin{array}{l}0.483^{*} \\
0.223^{6}\end{array}$ & $\begin{array}{l}0.184 \\
0.184\end{array}$ & $\begin{array}{l}0.551 \\
0.275\end{array}$ \\
\hline Lp2 & $\begin{array}{l}0.394^{*} \\
0.015^{16}\end{array}$ & $\begin{array}{l}-0.036 \\
-0.036\end{array}$ & $\begin{array}{l}0.073 \\
0.073\end{array}$ & $\begin{array}{l}0.043 \\
0.043\end{array}$ & $\begin{array}{l}-0.079 \\
-0.079\end{array}$ & $\begin{array}{l}0.052 \\
0.052\end{array}$ & $\begin{array}{l}0.324^{*} \\
0.063^{10}\end{array}$ & $\begin{array}{l}0.066 \\
0.066\end{array}$ & $\begin{array}{l}0.123 \\
0.123\end{array}$ & $\begin{array}{l}0.114 \\
0.114\end{array}$ \\
\hline Lp4 & $\begin{array}{l}-0.083 \\
-0.083\end{array}$ & $\begin{array}{l}0.043 \\
0.043\end{array}$ & $\begin{array}{l}0.057 \\
0.057\end{array}$ & $\begin{array}{l}-0.009 \\
-0.009\end{array}$ & $\begin{array}{l}0.069 \\
0.069\end{array}$ & $\begin{array}{l}-0.002 \\
-0.002\end{array}$ & $\begin{array}{l}0.070 \\
0.070\end{array}$ & $\begin{array}{l}0.091 \\
0.091\end{array}$ & $\begin{array}{l}-0.034 \\
-0.034\end{array}$ & $\begin{array}{l}0.309 \\
0.212^{2}\end{array}$ \\
\hline Lp5 & $\begin{array}{l}0.385^{*} \\
0.040^{13}\end{array}$ & $\begin{array}{l}-0.037 \\
-0.037\end{array}$ & $\begin{array}{r}0.273^{*} \\
-0.001^{22}\end{array}$ & $\begin{array}{l}-0.006 \\
-0.006\end{array}$ & $\begin{array}{l}-0.132 \\
-0.132\end{array}$ & $\begin{array}{l}0.178 \\
0.178\end{array}$ & $\begin{array}{l}0.282^{*} \\
0.025^{10}\end{array}$ & $\begin{array}{l}0.264^{*} \\
0.046^{7}\end{array}$ & $\begin{array}{l}0.287^{*} \\
0.105^{5}\end{array}$ & $\begin{array}{l}0.450 \\
0.057\end{array}$ \\
\hline Lp12 & $\begin{array}{l}0.165 \\
0.165\end{array}$ & $\begin{array}{l}0.094 \\
0.094\end{array}$ & $\begin{array}{l}0.120 \\
0.120\end{array}$ & $\begin{array}{l}0.158^{*} \\
0.038^{10}\end{array}$ & $\begin{array}{l}0.238^{*} \\
0.028^{12}\end{array}$ & $\begin{array}{c}0.400^{*} \\
-0.011^{15}\end{array}$ & $\begin{array}{l}0.172 \\
0.172\end{array}$ & $\begin{array}{l}0.355^{*} \\
0.019^{10}\end{array}$ & $\begin{array}{l}0.069 \\
0.069\end{array}$ & $\begin{array}{l}-0.394 \\
-0.394\end{array}$ \\
\hline All & $\begin{array}{l}0.202 \\
0.036\end{array}$ & $\begin{array}{l}0.027 \\
0.027\end{array}$ & $\begin{array}{l}0.145 \\
0.063\end{array}$ & $\begin{array}{l}0.037 \\
0.018\end{array}$ & $\begin{array}{l}0.039 \\
0.005\end{array}$ & $\begin{array}{l}0.169 \\
0.066\end{array}$ & $\begin{array}{l}0.203 \\
0.083\end{array}$ & $\begin{array}{l}0.248 \\
0.093\end{array}$ & $\begin{array}{l}0.125 \\
0.089\end{array}$ & $\begin{array}{l}0.235 \\
0.100\end{array}$ \\
\hline $\begin{array}{l}\text { Overall } \\
\text { corrected } F_{\mathrm{IS}}\end{array}$ & ns & ns & ns & ns & ns & $\mathrm{ns}$ & ns & ns & ns & $\mathrm{ns}$ \\
\hline
\end{tabular}

Table 4. Loligo pealeii. Genetic substructuring among populations. Pairwise $F_{\text {ST }}$ values (below diagonal) and geographic distances in $\mathrm{km}$ (above diagonal). Two $F_{\mathrm{ST}}$ values are shown: before (number above) and after (number below; $F_{\mathrm{STcorr}}$ ) correction for null alleles. Numbers in bold indicate non-significant genetic difference. Statistical significance adjusted for multiple comparisons $=0.001$

\begin{tabular}{|c|c|c|c|c|c|c|c|c|c|c|}
\hline & Stn 1 & Stn 2 & Stn 3 & Stn 4 & Stn 5 & Stn 6 & Stn 7 & Stn 8 & Stn 9 & Stn 10 \\
\hline Stn 1 & 0 & 478 & 527 & 772 & 956 & 2966 & 311 & 979 & 661 & 481 \\
\hline Stn 2 & $\begin{array}{l}0.0974 \\
0.0858\end{array}$ & 0 & 90 & 316 & 492 & 2488 & 296 & 206 & 979 & 630 \\
\hline Stn 3 & $\begin{array}{l}0.0687 \\
0.0484\end{array}$ & $\begin{array}{l}0.0345 \\
0.0384\end{array}$ & 0 & 246 & 428 & 2448 & 294 & 269 & 125 & 456 \\
\hline Stn 4 & $\begin{array}{l}0.0909 \\
0.0808\end{array}$ & $\begin{array}{l}0.0526 \\
0.0520\end{array}$ & $\begin{array}{l}0.0208 \\
0.0236\end{array}$ & 0 & 184 & 2219 & 511 & 231 & 335 & 346 \\
\hline Stn 5 & $\begin{array}{l}0.0917 \\
0.0810\end{array}$ & $\begin{array}{l}0.0392 \\
0.0377\end{array}$ & $\begin{array}{l}0.0186 \\
0.0197\end{array}$ & $\begin{array}{l}0.0597 \\
0.0518\end{array}$ & 0 & 2039 & 693 & 555 & 231 & 170 \\
\hline Stn 6 & $\begin{array}{l}0.0947 \\
0.0836\end{array}$ & $\begin{array}{l}0.0665 \\
0.0679\end{array}$ & $\begin{array}{l}0.0228 \\
0.0250\end{array}$ & $\begin{array}{l}0.0380 \\
0.0294\end{array}$ & $\begin{array}{l}0.0575 \\
0.0509\end{array}$ & 0 & 2730 & 2592 & 2372 & 2086 \\
\hline $\operatorname{Stn} 7$ & $\begin{array}{l}0.0712 \\
0.0467\end{array}$ & $\begin{array}{l}0.0263 \\
0.0296\end{array}$ & $\begin{array}{l}0.0105 \\
0.0115\end{array}$ & $\begin{array}{l}0.0257 \\
0.0284\end{array}$ & $\begin{array}{l}0.0293 \\
0.0318\end{array}$ & $\begin{array}{l}\mathbf{0 . 0 1 0 8} \\
0.0185\end{array}$ & 0 & 172 & 528 & 688 \\
\hline Stn 8 & $\begin{array}{l}0.0830 \\
0.0663\end{array}$ & $\begin{array}{l}0.0468 \\
0.0530\end{array}$ & $\begin{array}{l}0.0021 \\
0.0065\end{array}$ & $\begin{array}{l}0.0256 \\
0.0252\end{array}$ & $\begin{array}{l}\mathbf{0 . 0 1 3 4} \\
0.0154\end{array}$ & $\begin{array}{l}\mathbf{0 . 0 3 1 0} \\
0.0236\end{array}$ & $\begin{array}{l}0.0226 \\
0.0260\end{array}$ & 0 & 231 & 527 \\
\hline Stn 9 & $\begin{array}{l}0.0610 \\
0.0434\end{array}$ & $\begin{array}{l}0.0336 \\
0.0356\end{array}$ & $\begin{array}{l}0.0135 \\
0.0144\end{array}$ & $\begin{array}{l}0.0307 \\
0.0333\end{array}$ & $\begin{array}{l}0.0477 \\
0.0465\end{array}$ & $\begin{array}{l}\mathbf{0 . 0 1 0 2} \\
0.0188\end{array}$ & $\begin{array}{l}0.0277 \\
\mathbf{0 . 0 0 7 5}\end{array}$ & $\begin{array}{l}0.0277 \\
0.0314\end{array}$ & 0 & 231 \\
\hline Stn 10 & $\begin{array}{l}0.0795 \\
0.0503\end{array}$ & $\begin{array}{l}\mathbf{0 . 0 1 3 7} \\
0.0217\end{array}$ & $\begin{array}{l}0.0236 \\
\mathbf{0 . 0 1 5 3}\end{array}$ & $\begin{array}{l}0.0403 \\
0.0369\end{array}$ & $\begin{array}{l}0.0361 \\
0.0361\end{array}$ & $\begin{array}{l}0.0373 \\
0.0305\end{array}$ & $\begin{array}{l}0.0079 \\
0.0060\end{array}$ & $\begin{array}{l}0.0203 \\
0.0180\end{array}$ & $\begin{array}{l}0.0155 \\
0.0078\end{array}$ & 0 \\
\hline
\end{tabular}

The Nova Scotia (Stn 1) samples were distinct from all other population samples, as indicated by high $F_{\text {STcorr }}$ values between that population and all others ( $F_{\text {STcorr }}$ values ranging from 0.0434 to 0.0858 ; Table 4 ). Based on $F_{\text {STcorr }}$ values, Gulf of Mexico samples (Stn 6) were distinct from all inshore spawning populations (Stns 2 to 5; Fig. 1), the mid-shelf Georges Bank (Stn 7) and the Nova Scotia population as well as offshore Veatch (Stn 8) and Hudson (Stn 9) canyons. However, the Gulf of Mexico samples were not distinctly different from the offshore Washington Canyon (Stn 10). The latter result might have been dependent on the small sample size of the Washington Canyon population $(\mathrm{n}=30)$ because the calculated $F_{\text {STcorr }}$ value was high (0.0305) although not significant.

A Mantel test showed no significant correlation between genetic and geographic distances among the 4 inshore summer samples (Stns 2 to 5 ; Fig. 1) (correla- 
tion coefficient $=0.18, \mathrm{~ns}$ ) or among all 10 sampling stations (correlation coefficient $=0.15, \mathrm{~ns}$ ). These results demonstrated that genetic differences could not be explained by isolation by distance (Slatkin 1993).

We found null alleles in all loci and in all but one population (Stn 2) (Table 3). Non-corrected and corrected $F_{\mathrm{ST}}$ values are provided in Table $4 ; 33$ out of 45 pairwise comparisons remained statistically significant after correction. On average, $F_{\text {STcorr }}$ values were $0.004( \pm 0.0089 \mathrm{SD})$ higher after correction than before. Five pairwise comparisons remained 'nonsignificant'; these $F_{\text {STcorr }}$ values decreased, on average, by $0.0016( \pm 0.0046 \mathrm{SD})$. Two $F_{\text {STcorr }}$ values became non-significant after correction (Stns 3-10 and 7-9) and decreased, on average, by $0.0135( \pm 0.0057 \mathrm{SD})$. Five $F_{\text {STcorr }}$ values became significant after correction (Stns 6-7, 6-8, 6-9, 5-8, and 2-10); these $F_{\text {STcorr }}$ values increased, on average, by $0.0027( \pm 0.006)$.

\section{DISCUSSION}

Loligo pealeii migrates seasonally north of Cape Hatteras (North Carolina). In late autumn, squids move from their inshore spawning grounds to more thermally stable waters in canyons along the edge of the continental shelf (Summers 1983). Our microsatellite data provided strong genetic evidence for multiple stocks of $L$. pealeii along the Atlantic coast of the USA. At least 4 distinct spawning populations occur from Cape Cod to Delaware, a geographic area that spans a length and breadth of approximately 700 and $100 \mathrm{~km}$, respectively, along the continental shelf. These results support the contention of Garthwaite et al. (1989) that multiple stocks exist in the $L$. pealeii fishery.

Precise molecular genetic markers such as microsatellite loci have only recently been developed for cephalopods (cf. Shaw 2003), and their application to cephalopod population structure has given mixed results. We found high levels of variability at all microsatellite loci, a trend similar to that seen in other cephalopods (Adcock et al. 1999, Reichow \& Smith 1999, Shaw et al. 1999, Naud et al. 2004). This was in contrast to low levels of variability previously detected in Loligo pealeii with allozymes (Garthwaite et al. 1989). Genetic differentiation among population samples has been demonstrated in the Order Octopoda (Octopus vulgaris, Murphy et al. 2002) and Order Sepiodea (Sepia officinalis, Perez-Losada et al. 2002; Sepiella maindroni, Zheng et al. 2001). However, a population genetic study of $S$. officinalis in the Adriatic Sea revealed a panmictic population (Garoia et al. 2004), while populations in the Atlantic and Mediterranean around the Iberian peninsula were genetically differentiated (Perez-Losada et al. 2002).
In the Teuthoidea, studies of the squids Illex argentinus (Adcock et al. 1999), Loligo vulgaris (Garoia et al. 2004) and L. opalescens (Reichow \& Smith 2001) failed to detect any genetically well-defined stocks. Based on 6 highly variable DNA microsatellite loci, Shaw et al. (2004) did not find genetic substructure in L. gahi on a geographic scale comparable to $L$. pealeii, but squid from the Peruvian coast were different from those off the Falkland Islands. In a similar fashion, Shaw et al. (1999) found only subtle substructure among populations of $L$. forbesi throughout most of its range, but observed more significant substructure at the isolated Azore Islands. All of the studies that did detect population structure were conducted in locations with marked oceanographic/geographic barriers to gene flow, while studies that reported homogeneity were from areas without conspicuous physical or hydrographic barriers. Our results for Loligo pealeii are strikingly different to those of previous studies, particularly to those conducted in areas without well-defined barriers. Several researchers have suggested that overlapping size cohorts and extended spawning periods seen in loliginids would tend to lead to genetic mixing (e.g. Macy \& Brodziak 2001, Reichow \& Smith 2001, Shaw et al. 2004). However, while L. pealeii exhibits patterns of cohort overlap and extension of spawning period similar to those of other loliginids, it nevertheless demonstrates genetic substructure. Improved information on species-specific migration and behavioral patterns - combined with data on maturity stage, size, and age - might begin to explain these differences in the genetic structure of cephalopods.

The recently developed program MICRO-CHECKER (van Oosterhout et al. 2004) indicated the presence of null alleles in all but 1 population and in up to all 5 loci (Table 3). The existence of null alleles in the same genetic markers has also been suggested by Shaw et al. (1999). We changed the homozygotes that were probably falsely assigned into heterozygotes, by introducing a new artificial smallest allele as the second allele. The null allele is likely to be an ancient primer site mutation that prevents the amplification of 1 allele during the PCR process. Over evolutionary time, the repeat-core associated with this flanking region has very likely accumulated stepwise mutations. Adding 1 artificial allele is therefore a conservative method to adjust for null alleles. One may question how the introduction of an additional allele influences the results, especially in cases where the artificial allele was only introduced in one but not in the other population. In response, we argue that because a new class of alleles (the null allele class vs. the 'visible' allele class) leads to a higher variation with which to work, the apparent $F_{\mathrm{ST}}$ value is actually increased. However, differences in apparent null allele frequency do reflect 'true' differences among popula- 
tions caused by drift. Adding the identified null allele uncovers some of the drift effects and population differentiation. Therefore, we consider the use of $F_{\text {STcorr }}$ values and the resulting population genetic structure as more reliable than using data uncorrected for null alleles. Looking at the changes in $F_{\text {STcorr }}$ values in more detail, it becomes obvious that in 38 out of 45 cases the correction did not change the statistical significance of the pairwise comparisons. In 2 cases, $F_{\text {STcorr }}$ values became statistically non-significant (Stns 3-10 and 7-9) and, in 5 cases, $F_{\text {STcorr }}$ values became statistically significant after correction. While there is no doubt about the existence of genetically different inshore stocks, these 5 changes in- volved the connection of Gulf of Mexico to midshelf (Stn 7) and offshore populations (Stns 8 and 9), and in 3 cases inshore-to-offshore relationships (Stns 2-10 and 5-9). All of these values need to be interpreted cautiously. The non-significant $F_{\text {STcorr }}$ value between inshore Long Island (Stn 3) and offshore Washington Canyon (Stn 10) is high (0.0305), and might be based solely on a sample size at Washington Canyon that was too small $(n=30)$ to detect genetic relatedness with statistical significance.

Given the lack of conspicuous physical oceanographic barriers to gene flow over the wide geographic range of Loligo pealeii (southern Caribbean to Nova Scotia) (Summers 1983), we did not expect to find population substructure within the southern New England/ Mid-Atlantic region. To what can we attribute this genetic differentiation? Our isolation-by-distance analysis showed no clear pattern of genetic differentiation based on geographic distances. One explanation is that animals are homing to their natal spawning grounds, a phenomenon demonstrated in some fish species (e.g. Cury 1994, Thorrold et al. 2001). An alternative explanation is that animals are travelling together in distinct spawning groups that do not show fidelity to particular sites. These groups may come together (either in mixed groups or in close proximity to each other) in offshore canyons to overwinter, and then re-form before migrating back to spawning sites in the spring. This type of migratory event would require an active behavioural process to differentiate and prefer 'own' over other subpopulations. Recognition and preference of own shoal members is well known in fish (Krause et al. 2000) but has not previously been shown in molluscs. If this type of recognition could be demonstrated, it would offer new insights into the biology of squid.

We sampled 3 offshore over-wintering stations along the shelf and found that squids at 2 offshore canyons (Stns 8 and 10, both sampled during winter of 2001-2002) did not show significant differentiation from an inshore summer population (Stn 3). We considered only the very low and non-significant $F_{\text {STcorr }}$ value (0.0065) between Stns 3 and 8 to be a reliable indication for a connection between an inshore and an offshore sample. However, other offshore samples were genetically different from all the other inshore samples, while showing little differentiation to each other (Fig. 1b). There are several possible explanations for this phenomenon. (1) Sample sizes from the offshore canyons were small ( $\mathrm{n}=20$ to 34 ), especially compared to some inshore samples. These small sample sizes may have produced non-significant results when comparing offshore populations. Perhaps larger sample sizes from each canyon would have revealed differentiation between offshore stations. (2) Offshore canyons represented a population that is distinct from the inshore populations. However, this does not seem likely, given the known migratory movements of Loligo pealeii. Instead, since most offshore canyons were differentiated from most inshore stations, this raises the question of where these offshore populations migrate in summer. It is possible that these offshore samples represent additional inshore stocks and that a finer sampling schedule would show these populations inshore in summer. Additionally, the inshore populations that we found may migrate to other winter canyons that we did not sample. It is remarkable that despite such long-distance migrations, squids apparently do not interbreed with other stocks.

The Nova Scotia samples (Stn 1) were genetically distinct from all inshore and offshore samples. Pairwise $F_{\text {ST }}$ values were much higher between Nova Scotia and all other groups than any other pairwise samples. Oceanic currents in this area may create a barrier to gene flow and cause a high degree of separation. At the opposite geographic location sampled - the northern Gulf of Mexico - samples were distinct from all but the offshore population at Washington Canyon (Stn 10). However, these data need to be considered cautiously because the results changed after correcting for null alleles. One explanation of the nonsignificant difference to Washington Canyon (Stn 10) might be based on the small sample size. Alternatively, it may indicate that squid paralarvae from the Gulf of Mexico make their way during the winter to offshore areas along the Atlantic coast by travelling first in the Gulf of Mexico gyre and then entering the Gulf Stream, a phenomenon that has been observed for some fish species (R. Scheltema pers. comm.). Mariculture trials on Loligo opalescens indicate that squid paralarvae may stay in the plankton for up to 1 to 2 mo before they are large enough to school and to control their position in the water column (Yang et al. 1986).

Comparison of our findings with population genetic studies on fish species shows that genetically differentiated populations can arise and persist in the absence of physical barriers or great distance. In most cases, the type of genetic markers used plays an important role in 
the detection of genetic substructuring. Some early reports of broad genetic uniformity based on allozymes have been contradicted by subsequent analysis using mtDNA and the most sensitive markers for small scale and short-term gene flow-DNA microsatellites (Bohonak 1999, Hellberg et al. 2002).

Microsatellites have indicated significant genetic divergence in red drum Sciaenops ocellatus across the northern Gulf of Mexico (mean $F_{\mathrm{ST}}=0.003$ ) at a scale from 150 to $2000 \mathrm{~km}$ (Gold \& Turner 2002). The cleaner gobi Elacatinus evelynae, with a pelagic stage of $21 \mathrm{~d}$, showed strong genetic differentiation $\left(F_{\mathrm{ST}}=70 \%\right)$ based on the mtDNA Cytochrome $b$ gene (Taylor et al. 2003). These results show that strong phylogeographic structure can develop in the Caribbean Sea between marine populations separated by as little as $23 \mathrm{~km}$ for species that have potential for long-distance larval dispersal. Genetic differentiation between populations of apogonids at adjacent reefs (10 to $80 \mathrm{~km}$ ) of the Great Barrier Reef has also been found by G. Gerlach (unpubl. data) using DNA microsatellite markers. A recent study of Atlantic cod Gadus morhua, a species located in a similar geographic region as Loligo pealeii, also indicated the existence of genetically differentiated populations. A weak, but consistent, differentiation was detected (using 10 microsatellite loci) among fish from 6 capture sites that spanned a distance of $300 \mathrm{~km}$ (Knutsen et al. 2003). The average $F_{\mathrm{ST}}$ value for all microsatellite loci was small (0.0023), but was statistically highly significant, even though cod populations intermingled inshore during summer and autumn feeding migrations. Similar genetic sub-structure has been observed in other cod studies of cod (Ruzzante et al. 1996, 1998, 2000), herring Clupea harengus (McPherson et al. 2001), European sea bass Dicentrarchus labrax (Naciri et al. 1999), European hake Merluccius merluccius (Lundy et al. 2000), and Pacific ocean perch Sebastes alutus (Withler et al. 2001).

Overall, these studies (in addition to our preliminary data) demonstrate that microsatellite markers are capable of distinguishing genetic differentiation down to a scale of tens of kilometers in at least some species with limited dispersal. However, the degree of genetic differentiation that we observed in populations of Loligo pealeii was, on average, higher than what was found in these other studies.

The implications of population structure in Loligo pealeii for current fisheries management are 2 -fold. (1) Separate inshore spawning groups should not be treated as a single unit stock. (2) The intensive offshore fishery may be impacting the inshore fishery as well as the genetic composition of discrete spawning stocks. If squid are travelling in discrete, related groups when migrating from offshore canyons to inshore spawning sites (whether showing spawning site fidelity or not), then targeted, intensive winter fishing in specific offshore canyons could potentially impact or even eliminate specific local summer stocks. Fishery managers must consider these potential interactions when planning for separate stock quotas. There is much to learn about the migratory and reproductive strategies of mobile loliginid squids, which play a central role in most coastal marine ecosystems.

Acknowledgements. We acknowledge funding from WHOI Sea Grant NA16RG2273, the Massachusetts Environmental Trust (\#98-04), and the Sholley Foundation. We are particularly grateful for specimens and fishery-related discussions with S. Cadrin and J. Brodziak of the Northeast Fisheries Science Center, NMFS, Woods Hole. M. Simonitsch, A. Howe, L. Hendrickson, S. Murawski and D. Pauly also provided stimulating discussions of our findings, and B. Beardsley of Woods Hole Oceanographic Institution explained oceanographic features. We thank the Northeast Fisheries Science Center (NMFS, Woods Hole), Massachusetts Department of Marine Fisheries, G. Monsen of Seafreeze, M. Simonitsch, D. Simpson (Connecticut Department of Environmental Protection), D. Byrne (New Jersey Department of Fish, Game and Wildlife) and S. Michels (Delaware Fish and Wildlife) for assistance in collecting samples. Thanks to M. Cox, S. Sit, and A. Abbott for processing samples.

\section{LITERATURE CITED}

Adcock GJ, Shaw PW, Rodhouse PG, Carvalho GR (1999) Microsatellite analysis of genetic diversity in the squid Illex argentinus during a period of intensive fishing. Mar Ecol Prog Ser 187:171-178

Belkhir K, Borsa P, Goudet J, Chikhi L, Bonhomme F (1997) Genetix v. 3.0, logiciel sous Windows TM pour la génétique des populations. Laboratoire Génome et Populations, Université Montpellier 2, Montpellier

Bohonak AJ (1999) Dispersal, gene flow, and population structure. Q Rev Biol 74:21-45

Boyle PR, Boletzky SV (1996) Cephalopod populations: definitions and dynamics. Philos Trans R Soc Lond B 351: 985-1002

Buresch KM, Hanlon RT, Maxwell MR, Ring S (2001) Microsatellite DNA markers indicate a high frequency of multiple paternity within individual field-collected egg capsules of the squid Loligo pealeii. Mar Ecol Prog Ser 210:161-165

Cavalli-Sforza LL, Edwards AWF (1967) Phylogenetic analysis: models and estimation procedures. Am J Hum Genet 19:233-257

Cury P (1994) Obstinate nature: an ecology of individuals. Thoughts on reproductive behavior and biodiversity. Can J Fish Aquat Sci 51:1664-1673

Garoia F, Guarniero I, Ramsak A, Ungaro N, Landi M, Piccinetti C, Mannini P, Tinti F (2004) Microsatellite DNA variation reveals high gene flow and panmictic populations in the Adriatic shared stocks of the European squid and cuttlefish (Cephalopoda). Heredity 93:166-174

Garthwaite RL, Berg CJ, Harrigan J (1989) Population genetics of the common squid Loligo pealei LeSueur, 1821, from Cape Cod to Cape Hatteras. Biol Bull (Woods Hole) 177:287-294

Gold JR, Turner TF (2002) Population structure of red drum (Sciaenops ocellatus) in the northern Gulf of Mexico, as 
inferred from variation in nuclear-encoded microsatellites. Mar Biol 140:249-265

Goudet J (1995) Fstat version 1.2: a computer program to calculate F statistics. J Hered 86:427-437

Graves JE (1998) Molecular insights into the population structures of cosmopolitan marine fishes. J Hered 89:427-437

Hatfield EMC, Hanlon RTH, Forsythe JW, Grist EPM (2001) Laboratory testing of a growth hypothesis for juvenile squid Loligo pealeii (Cephalopoda:Lolognidae). Can J Fish Aquat Sci 58:845-857

Hellberg ME, Burton RS, Neigel JE, R. PS (2002) Genetic assessment of connectivity among marine populations. Bull Mar Sci 70:273-290

Knutsen H, Jorde PE, Andre C, Stenseth NC (2003) Finescaled geographical population structuring in a highly mobile marine species: the Atlantic cod. Mol Ecol 12: 385-394

Krause J, Butlin RK, Peuhkuri N, Pritchard VL (2000) The social organization of fish shoals: a test of the predictive power of laboratory experiments for the field. Biol Rev Camb Philos Soc 75:477-501

Lundy CJ, Rico C, Hewitt GM (2000) Temporal and spatial genetic variation in spawning grounds of European hake (Merluccius merluccius) in the Bay of Biscay. Mol Ecol 9: 2067-2079

Macy WK, Brodziak JKT (2001) Seasonal maturity and size at age of Loligo pealeii in waters of southern New England. ICES J Mar Sci 58:852-864

Mantel N (1967) The detection of disease clustering as a generalized regression approach. Cancer Res 27:209-220

Maxwell MR, Buresch KM, Hanlon RT (2000) Pattern of inheritance of microsatellite loci in the squid Loligo pealeii (Mollusca: Cephalopoda). Mar Biotechnol 2:517-521

McPherson AA, Stephenson RL, O'Reilly PT, Jones MW, Taggart CT (2001) Genetic diversity of coastal Northwest Atlantic herring populations: implications for management. J Fish Biol 59:356-370

Murphy JMBE, Key LN, Boyle PR (2002) Microsatellite DNA markers discriminate between two Octopus vulgaris (Cephalopoda: Octopoda) fisheries along the northwest African coast. Bull Mar Sci 71:545-553

Naciri M, Lemaire C, Borsa P, Bonhomme F (1999) Genetic study of the Atlantic/Mediterranean transition in sea bass (Dicentrarchus labrax). J Hered 90:591-596

Naud MJ, Hanlon RT, Hall KC, Shaw PW, Havenhand JN (2004) Behavioral and genetic assessment of mating success in a natural spawning aggregation of the giant cuttlefish (Sepia apama) in southern Australia. Anim Behav 67: 1043-1050

NEFSC (1996) Report of the 21st northeast regional stock assessment workshop (21st SAW): stock assessment review comittee (SARC) consensus summary of assessments. Northeast Fisheries Science Center, Woods Hole, MA, p 200

Perez-Losada M, Guerra A, Carvalho GR, Sanjuan A, Shaw PW (2002) Extensive population subdivision of the cuttlefish Sepia officinalis (Mollusca:Cephalopoda) around the Iberian Peninsula indicated by microsatellite DNA variation. Heredity 89:417-424

Reichow D, Smith MJ (1999) Highly variable microsatellites in the California market squid Loligo opalescens. Mar Biotech 1:403-406

Reichow D, Smith MJ (2001) Microsatellites reveal high levels of gene flow among populations of the California squid Loligo opalescens. Mol Ecol 10:1101-1109

Ruzzante DE, Taggart T, Cook D, Goddard S (1996) Genetic differentiation between inshore and offshore Atlantic cod
(Gadus morhua) off Newfoundland: microsatellite DNA variation and antifreeze level. Can J Fish Aquat Sci 53: $634-645$

Ruzzante DE, Taggart CT, Cook D (1998) A nuclear DNA basis for shelf- and bank-scale population structure in northwest Atlantic cod (Gadus morhua): Labrador to Georges Bank. Mol Ecol 7:1663-1680

Ruzzante DE, Taggart CT, Lang S, Cook D (2000) Mixedstock analysis of Atlantic cod near the Gulf of St. Lawrence based on microsatellite DNA. Ecol Appl 10: 1090-1109

Sambrook J, Fritsch EF, Maniatis T (1989) Molecular cloning: a laboratory manual. Cold Spring Harbor Laboratory Press, New York

Shaw PW (2003) Polymorphic microsatellite DNA markers for the assessment of genetic diversity and paternity testing in the giant cuttlefish, Sepia apama (Cephalopoda). Conserv Genet 4:533-535

Shaw PW, Pierce GJ, Boyle PR (1999) Subtle population structuring within a highly vagile marine invertebrate, the veined squid Loligo forbesi, demonstrated with microsatellite DNA markers. Mol Ecol 8:407-417

Shaw PW, Arkhipkin AI, Adcock GJ, Burnett WJ, Carvalho GR, Scherbich JN, Villegas PA (2004) DNA markers indicate that distinct spawning cohorts and aggregations of Patagonian squid, Loligo gahi, do not represent genetically discrete subpopulatio ns. Mar Biol 144: 961-970

Slatkin M (1993) Isolation by distance in equilibrium and nonequilibrium populations. Evolution 47:264-279

Summers WC (1983) Loligo pealeii. In: Boyle PR (ed) Cephalopod life cycles. Academic Press, New York, p 115-142

Takezaki N, Nei M (1996) Genetic distances and reconstruction of phylogenetic trees from microsatellite DNA. Genetics 14:389-399

Taylor MI, Morley JI, Rico C, Balshine S (2003) Evidence for genetic monogamy and female-biased dispersal in the biparental mouthbrooding cichlid Eretmodus cyanostictus from Lake Tanganyika. Mol Ecol 12:3173-3177

Thorrold SR, Latkoczy C, Swart PK, Jones CM (2001) Natal homing in a marine fish metapopulation. Science 291:297-299

van Oosterhout C, Hutchinson WF, Derek PMW, Shipley P (2004) MICRO-CHECKER: software for identifying and correcting genotyping errors in microsatellite data. Mol Ecol Notes 4:535-538

Waples RS (1998) Separating the wheat from the chaff: patterns of genetic differentiation in high gene flow species. J Hered 89:438-450

Ward RD, Woodwark M, Skibinski DOF (1994) A comparison of genetic diversity levels in marine, freshwater, and anadromous fishes. J Fish Biol 44:213-232

Withler RE, Beacham TD, Schulze AD, Richards LJ, Miller KM (2001) Co-existing populations of Pacific ocean perch, Sebastes alutus in Queen Charlotte Sound, British Columbia. Mar Biol 139:1-12

Yang WT, Hixon RF, Turk PE, Krejci ME, Hulet WH, Hanlon RT (1986) Growth, behavior, and sexual maturation of the market squid, Loligo opalescens, cultured through the life cycle. Fish Bull 84:771-798

Zheng XD, Wang RC, Wang XF, Xiao S, Chen B (2001) Genetic variation in populations of the common Chinese cuttlefish Sepiella maindroni (Mollusca: Cephalopoda) using allozymes and mitochondrial DNA sequence analysis. J Shellfish Res 20:1159-1165

Submitted: November 11, 2004; Accepted: September 26, 2005 Proofs received from author(s): February 9, 2006 